University of Nebraska - Lincoln DigitalCommons@University of Nebraska - Lincoln

2014

\title{
Global assessment of damage to coastal ecosystem vegetation from tropical storms
}

Christopher Potter

NASA Ames Research Center, Moffett Field, CA 94035, chris.potter@nasa.gov

Follow this and additional works at: http://digitalcommons.unl.edu/nasapub

Potter, Christopher, "Global assessment of damage to coastal ecosystem vegetation from tropical storms" (2014). NASA Publications. 184.

http://digitalcommons.unl.edu/nasapub/184

This Article is brought to you for free and open access by the National Aeronautics and Space Administration at DigitalCommons@University of Nebraska - Lincoln. It has been accepted for inclusion in NASA Publications by an authorized administrator of DigitalCommons@University of Nebraska - Lincoln. 


\title{
Global assessment of damage to coastal ecosystem vegetation from tropical storms
}

\author{
Christopher Potter* \\ NASA Ames Research Center, Moffett Field, CA 94035, United States
}

(Received 4 February 2014; accepted 28 February 2014)

\begin{abstract}
This study reports on the first comprehensive global assessment of tropical storm (TS) impacts on coastal ecosystem vegetation along the landfall pathways of major hurricanes, cyclones and typhoons using satellite data of land cover vegetation for the years 2006 to 2012. Wind damage has been shown to reduce live vegetation pools of carbon, accelerate ecosystem respiration fluxes of carbon dioxide and thereby represent a potentially significant positive feedback to terrestrial greenhouse gas emissions. Based on quarterly detection of changes in Moderate Resolution Imaging Spectroradiometer (MODIS) satellite vegetation greenness, all major TS pathways during the time period were ranked in terms of area of vegetation damage observed. Comparison of vegetation disturbance area along major TS pathways to average rates of disturbance within the same coastal zones (for years during which no TS activity was observed) verified the satellite capability to detect TS ecosystem impacts.
\end{abstract}

\section{Introduction}

In recent decades, economic damage from tropical storms (TS) around the world has increased notably (Emanuel 2005; Weinkle, Maue, and Pielke 2012). Intense cyclones and hurricanes can extensively damage coastal vegetation and have the potential to alter ecosystem structure and function by accelerating rates of biomass transfer (from live standing pools to down and decomposing pools) and associated nutrient cycles (Brokaw and Walker 1991; Whigham et al. 1991). Quantifying these TS disturbance areas on a global level is crucial to evaluating regional carbon budgets, and for improving land use management decisions following TS events.

Damage to coastal vegetation can result from a combination of high wind speeds, waves from storm surges and floods following heavy rainfall. Several previous studies have quantified vegetation disturbance produced by selected TS events (Zimmerman et al. 1994; Zhao, Allen, and Sharitz 2006; Chambers et al. 2007; Negrón-Juárez et al. 2010; Rogan et al. 2011; Lewis and Bannar-Martin 2012). A small set of post-storm survey studies have examined the relationships between field-measured tree mortality and vegetation cover indices that can be computed from the satellite sensor data from Landsat and the Moderate Resolution Imaging Spectroradiometer (MODIS), which in turn can be broadly applied to regional forest ecosystems impacted by TS events (Chambers et al. 2007; Rogan et al. 2011).

The purpose of this study was to conduct the first comprehensive global assessment of TS impacts on coastal ecosystem vegetation along the landfall pathways of major hurricanes,

*Corresponding author. Email: chris.potter@nasa.gov

(C) 2014 This work was authored as part of the Contributor's official duties as an Employee of the United States Government and is therefore a work of the United States Government. In accordance with 17 U.S.C. 105, no copyright protection is available for such works under U.S. Law 
cyclones and typhoons using MODIS remote sensing data from the years 2006 to 2012. A consistent method to detect changes in the MODIS satellite vegetation index (VI), based on the previously published studies by Potter et al. (2005, 2007) and Rogan et al. (2011), within landfall zones was applied to all major TS events during this seven-year period, ranked by their maximum recorded wind speeds over land areas. Vegetation damage areas were assessed along major TS pathways and compared to disturbance rates within the same coastal zones during years when no TS activity was observed.

\section{Methods and methods}

A new MODIS product called the 'Quarterly Indicator of Cover Change' (QUICC) has been implemented at NASA Ames Research Center. The QUICC product is based on comparison of MODIS global VI images at the exact same time period each year (ending of March, June, September and December) in consecutive years. Seasonal variation in perennial canopy cover can be controlled for in the QUICC product's quarterly baseline.

The 5600-m resolution global MODIS QUICC product identifies all land areas that have lost at least $40 \%$ of their perennial green vegetation cover over the past year. This level of green canopy loss is commonly associated with major forest wildfires and deforestation events detected using previously published satellite time-series data analyses (Potter et al. 2005, 2007), which constitute the verified foundation for the QUICC methodology. Timeliness of the QUICC product enables organizations that are monitoring forests and woodlands anywhere in the world, with the capacity to respond within weeks or months (rather than years) to threats to protected reserves and parks.

Collection 5 MODIS data sets beginning in the year 2005 were obtained from NASA's Land Processes Distributed Active Archive Center (LP-DACC 2007) site. MODIS enhanced vegetation index (EVI) layers (MOD13C2 Terra vegetation indices) were obtained from the spatial composites of the gridded 16-day 1-km MOD13A2 products. MODIS EVI has been calculated from red, blue and NIR bands as described by Huete et al. (2002). EVI data were obtained as a level-3 product projected on a $0.05^{\circ}(5600-\mathrm{m})$ geographic climate modelling grid (CMG). Cloud-free global EVI coverage at 5600-m spatial resolution was achieved by replacing cloudy image values with the historical MODIS time-series EVI record.

For this study, the December QUICC products at the 5600-m resolution of vegetation cover loss were assessed within a 50-km buffer zone surrounding the vector landfall pathways of all major TS events recorded between 2006 and 2012 in the IBTrACS (International Best Track Archive for Climate Stewardship) global tropical cyclone best track data record (Knapp et al. 2010). The IBTrACS vector line for each TS was first intersected with the continental land boundary to determine the landfall location and TS pathway inland (Figure 1). The date of each TS path, its maximum wind speed (MWS in knots) and minimum central pressure (MSP in mb) at landfall were assigned from the IBTrACS database. According to the WMO (1983), the maximum sustained wind is a 10-min average wind speed at 10-m height above level ground. The major TS pathways selected all had a recorded MWS of greater than 65 knots $\left(120 \mathrm{~km} \mathrm{hr}^{-1}\right)$ at landfall. As exceptions, owing to the potential for snow and deciduous forest cover in the northeastern United States and Canada in December, Hurricanes Florence (in 2006) and Sandy (in 2012) were not included in this analysis.

Tests of statistical significance between the areas of QUICC vegetation change points during TS seasons and the average area disturbed in those years between the TS events at any given landfall path location were carried out using the two-sample Mann-Whitney $U$ test and the Kolmogorov-Smirnov $(\mathrm{K}-\mathrm{S})$ test. These non-parametric methods compare the 


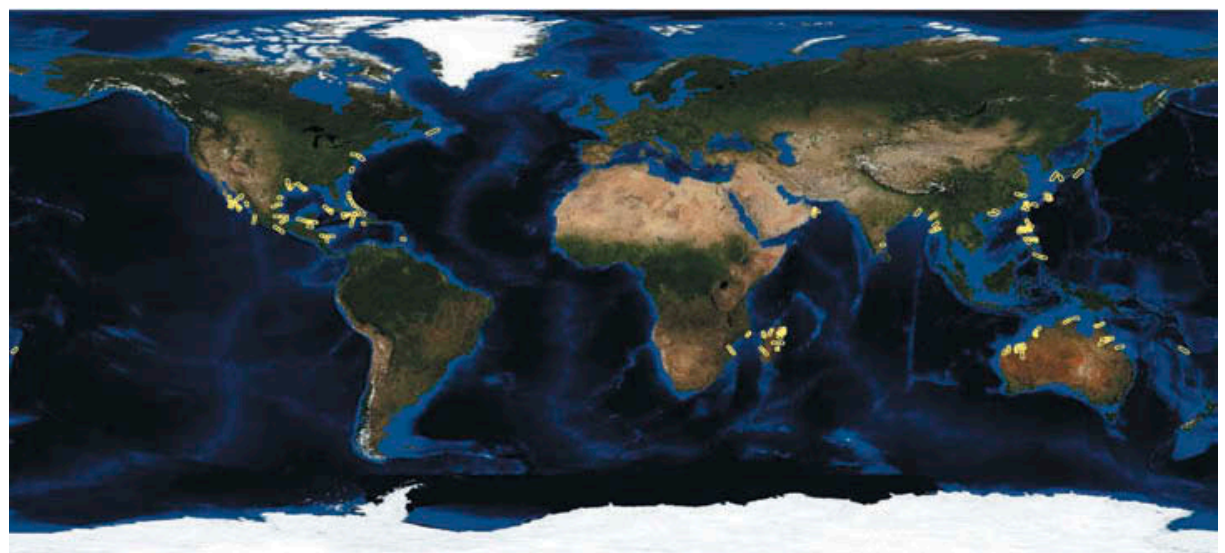

Figure 1. IBTrACS major TS events recorded from 2006 to 2012 showing the 50-km landfall buffer zones as yellow-coloured polygons.

cumulative distributions of two data sets (Lehmann 2006) and do not assume that data were sampled from Gaussian distributions (nor any other defined distributions).

The K-S test reports the maximum difference between the two cumulative distributions and calculates a $p$-value from that difference and the sample sizes. It tests the null hypothesis that both groups were sampled from populations with identical distributions according to different medians, variances or outliers. If the $\mathrm{K}-\mathrm{S} p$-value is small (i.e. $<0.05$ ), it can be concluded that the two groups were sampled from populations with significantly different distributions. To achieve an adequate sample size for these tests of significance, all TS were considered together in the distribution comparisons.

\section{Results and discussion}

A consistently higher QUICC vegetation disturbance area was detected within $50-\mathrm{km}$ buffer zones surrounding the vector landfall paths of most major TS events recorded between 2006 and 2012, compared to the QUICC vegetation disturbance areas within the same 50-km landfall buffer zones during years when no major TS events were recorded (Table 1). The ratio of QUICC areas from the year of each TS to all other years in the 2006 to 2012 period averaged $2.4: 1$, and the ratio exceeded 4:1 in 13 of the 76 major TS reported.

The $p$-value for both the Mann-Whitney $U$-test and the $\mathrm{K}-\mathrm{S}$ ranked sum comparison was less than 0.035 , such that it could be concluded that the two groups of QUICC points (TS year and the average for all other years) were sampled from populations with significantly different distributions. Only three major TS events were associated with zero QUICC points detected within their 50-km landfall buffer zones (Table 1). These three TS events were not among the strongest TS events in the 2006-2012 listing, since they were recorded with MWS at landfall of less than 91 knots and MSP higher than $935 \mathrm{mb}$.

Closer examination of the TS events that were associated with the most extensive vegetation disturbance area (of between 1700 and $7000 \mathrm{~km}^{2}$ each) was headed by Cyclone Fanele (Figure 2), which made landfall along the southwestern coastline of Madagascar in 2009 where it destroyed many buildings and flooded large areas (OCHA 2009). Poststorm surveys of the dry tropical forest areas affected by TS Fanele were conducted by Lewis and Bannar-Martin (2012), who found that over 95\% of trees experienced some 
Table 1. Major TS events from 2006 to 2012 ranked by the area of vegetation disturbance from QUICC totals associated with the TS in the surrounding 50-km landfall buffer zone.

\begin{tabular}{|c|c|c|c|c|c|}
\hline TS name & Year & $\begin{array}{l}\text { WMO Wind } \\
\text { speed (knots) }\end{array}$ & $\begin{array}{l}\text { WMO } \\
\text { Pressure } \\
\text { (mb) }\end{array}$ & $\begin{array}{l}\text { Ratio of QUICC } \\
\text { points in year of TS } \\
\text { to all other years }\end{array}$ & $\begin{array}{c}\text { Detected area of } \\
\text { vegetation disturbance } \\
\left(\mathrm{km}^{2}\right)\end{array}$ \\
\hline Fanele & 2009 & 90 & 942 & 4.41 & 6931 \\
\hline Yasi & 2011 & 110 & 930 & 4.16 & 6805 \\
\hline Gustav & 2008 & 125 & 943 & 2.48 & 2666 \\
\hline Irene & 2011 & 105 & 957 & 1.65 & 2446 \\
\hline Monica & 2006 & 135 & 917 & 1.48 & 2258 \\
\hline Ike & 2008 & 115 & 945 & 2.12 & 2195 \\
\hline Durian & 2006 & 90 & 940 & 5.17 & 1756 \\
\hline Alex & 2010 & 90 & 948 & 3.61 & 1756 \\
\hline Nesat & 2011 & 80 & 950 & $>2.0$ & 1348 \\
\hline Isaac & 2012 & 70 & 966 & 2.22 & 1066 \\
\hline Sidr & 2007 & 115 & 944 & 3.92 & 1004 \\
\hline Nalgae & 2011 & 95 & 935 & $>2.0$ & 878 \\
\hline Xangsane & 2006 & 85 & 940 & 7.09 & 815 \\
\hline Nanmadol & 2011 & 90 & 945 & 12.50 & 784 \\
\hline Megi & 2010 & 125 & 885 & 3.60 & 753 \\
\hline Favio & 2007 & 95 & 935 & 0.45 & 659 \\
\hline Dolly & 2008 & 75 & 967 & 1.85 & 659 \\
\hline Jokwe & 2008 & 85 & 962 & 0.97 & 596 \\
\hline Dean & 2007 & 110 & 935 & 1.85 & 533 \\
\hline Felix & 2007 & 135 & 939 & 4.17 & 502 \\
\hline Lua & 2012 & 85 & 935 & 2.91 & 502 \\
\hline Fengshen & 2008 & 85 & 955 & 3.00 & 470 \\
\hline Bingiza & 2011 & 85 & 958 & $>2.0$ & 470 \\
\hline Jim & 2006 & 80 & 955 & 1.79 & 439 \\
\hline Shanshan & 2006 & 80 & 950 & 0.67 & 408 \\
\hline Karl & 2010 & 110 & 956 & 5.20 & 408 \\
\hline Richard & 2010 & 85 & 977 & 3.27 & 376 \\
\hline Bolaven & 2012 & 90 & 925 & $>2.0$ & 376 \\
\hline Clovis & 2007 & 55 & 983 & 6.60 & 345 \\
\hline Norbert & 2008 & 95 & 954 & 0.50 & 345 \\
\hline Saomai & 2006 & 100 & 935 & 1.62 & 314 \\
\hline Cimaron & 2006 & 100 & 920 & 0.55 & 314 \\
\hline George & 2007 & 110 & 902 & 1.02 & 314 \\
\hline Sepat & 2007 & 90 & 940 & 4.29 & 314 \\
\hline Humberto & 2007 & 80 & 985 & 0.48 & 314 \\
\hline Ivan & 2008 & 95 & 935 & 1.33 & 314 \\
\hline Jade & 2009 & 60 & 975 & 5.00 & 314 \\
\hline Kompasu & 2010 & 80 & 960 & 2.61 & 314 \\
\hline Roke & 2011 & 80 & 950 & 1.62 & 314 \\
\hline Clare & 2006 & 75 & 960 & 0.63 & 282 \\
\hline Ului & 2010 & 80 & 967 & 0.29 & 282 \\
\hline Phet & 2010 & 65 & 980 & 1.29 & 282 \\
\hline John & 2006 & 95 & 958 & 0.30 & 251 \\
\hline Fanapi & 2010 & 80 & 950 & $>2.0$ & 251 \\
\hline Wipha & 2007 & 100 & 925 & 2.80 & 220 \\
\hline Nargis & 2008 & 90 & 962 & 0.68 & 188 \\
\hline Paloma & 2008 & 125 & 951 & $>2.0$ & 188 \\
\hline Jimena & 2009 & 95 & 965 & 0.16 & 157 \\
\hline Heidi & 2012 & 65 & 971 & 15.00 & 157 \\
\hline Indlala & 2007 & 95 & 935 & 0.63 & 125 \\
\hline
\end{tabular}


Table 1. (Continued).

\begin{tabular}{|c|c|c|c|c|c|}
\hline TS name & Year & $\begin{array}{l}\text { WMO Wind } \\
\text { speed (knots) }\end{array}$ & $\begin{array}{l}\text { WMO } \\
\text { Pressure } \\
(\mathrm{mb})\end{array}$ & $\begin{array}{l}\text { Ratio of QUICC } \\
\text { points in year of TS } \\
\text { to all other years }\end{array}$ & $\begin{array}{c}\text { Detected area of } \\
\text { vegetation disturbance } \\
\left(\mathrm{km}^{2}\right)\end{array}$ \\
\hline Sinlaku & 2008 & 80 & 960 & 1.14 & 125 \\
\hline Rene & 2010 & 65 & 980 & 2.40 & 125 \\
\hline Giri & 2010 & 105 & 950 & 0.80 & 125 \\
\hline Jelawat & 2012 & 90 & 930 & 12.00 & 125 \\
\hline Glenda & 2006 & 70 & 962 & 0.49 & 94 \\
\hline Lane & 2006 & 110 & 954 & 1.06 & 94 \\
\hline Henriette & 2007 & 70 & 972 & $>2.0$ & 94 \\
\hline Ida & 2009 & 70 & 985 & 0.67 & 94 \\
\hline Hubert & 2010 & 55 & 985 & 3.60 & 94 \\
\hline Tomas & 2010 & 80 & 990 & 1.00 & 94 \\
\hline Jova & 2011 & 85 & 974 & 1.50 & 94 \\
\hline Ernesto & 2012 & 80 & 979 & $>2.0$ & 94 \\
\hline Larry & 2006 & 100 & 945 & 0.02 & 63 \\
\hline Mala & 2006 & 90 & 966 & $>2.0$ & 63 \\
\hline Chebi & 2006 & 95 & 930 & 0.60 & 63 \\
\hline Gonu & 2007 & 77 & 970 & 1.00 & 63 \\
\hline Usagi & 2007 & 80 & 960 & 0.44 & 63 \\
\hline Fame & 2008 & 70 & 972 & 0.25 & 63 \\
\hline Hagupit & 2008 & 90 & 935 & 0.39 & 63 \\
\hline Magda & 2010 & 110 & 925 & 0.12 & 63 \\
\hline Vicente & 2012 & 80 & 950 & 0.29 & 63 \\
\hline Jangmi & 2008 & 100 & 925 & 0.55 & 31 \\
\hline Carlotta & 2012 & 90 & 976 & 3.00 & 31 \\
\hline Jaya & 2007 & 75 & 965 & 0.00 & 0 \\
\hline Giovanna & 2012 & 85 & 945 & 0.00 & 0 \\
\hline Sanba & 2012 & 90 & 935 & 0.00 & 0 \\
\hline
\end{tabular}

Note: Ratio ' $>2.0$ ' indicates that one or less QUICC points were detected on average along $50-\mathrm{km}$ landfall buffer zones during years other than the year of the corresponding TS event.

sort of damage (including 9\% mortality), and that understory and emergent trees experienced significantly higher mortality than canopy trees.

Cyclone Yasi, which made landfall in northern Queensland, Australia, in 2011 (Figure 2), was detected as the next most destructive TS event (2006-2012) in terms of the area of coastal vegetation affected (covering more than $6800 \mathrm{~km}^{2}$ ). The Yasi storm surge was estimated to have reached $7 \mathrm{~m}$ high and destroyed many structures along the coast, including sugar cane and banana plantations (Sun 2011). Hurricanes Gustav (2008) and Irene (2011) both made landfall across several Caribbean islands and then in different locations on the southern coast of the United States, each causing more than $2400 \mathrm{~km}^{2}$ of detectable damage to inland vegetation, according to the QUICC product results (Figure 2). Survey assessments reported by Negrón-Juárez et al. (2010) found that flooded forest areas in Louisiana were not severely damaged by Hurricane Gustav, whereas nonflooded forests and seasonally flooded hardwood (e.g. cottonwood and boxelder) bottomlands were heavily damaged by the extreme winds, with as high as $70 \%$ tree mortality. The Hurricane Irene timber damage survey carried out by aircraft in 2011 reported impacted forest areas as $21 \%$ with light damage and $6 \%$ with moderate-to-heavy damage, again mainly in hardwood stands (NCFS 2011). 

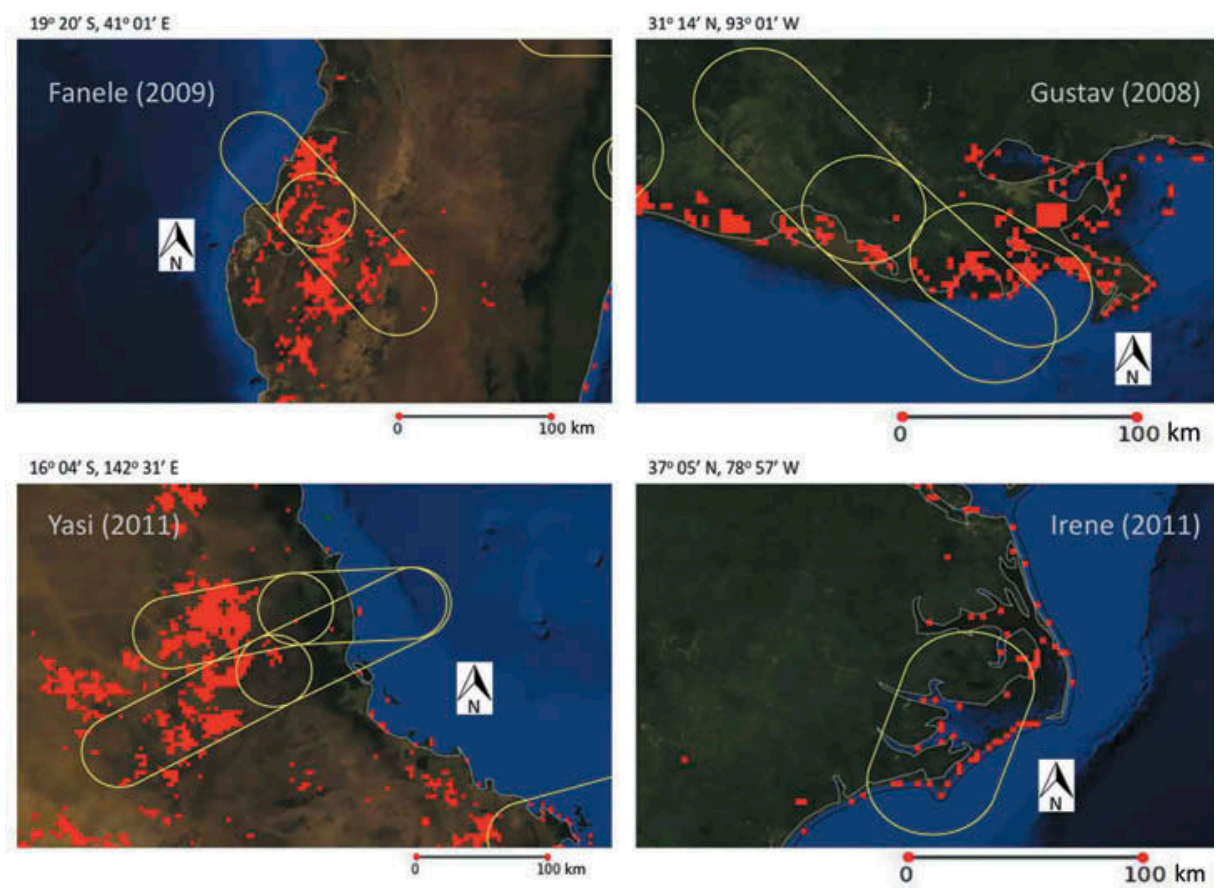

Figure 2. QUICC results (5600-m resolution pixels shaded in red for scales) along 50-km landfall buffer zones (as yellow-coloured polygons) associated with the most extensive vegetation disturbance areas of all major TS events recorded from 2006 to 2012. Geographic coordinates were shown for the northwestern corner point of each map.

The global relationship of MWS at landfall to area of vegetation disturbance from QUICC area summations (Table 1) showed a significant exponential correlation $(p<0.01)$, particularly at estimated MWS of greater than 100 knots at landfall (Figure 3). Given the fact that TS events can have varying wind speeds and direction patterns that would be influenced by local coastline geometry and inland topography (e.g. mountains, valleys, river courses), and that a 50-km buffer zone around the path of the storm may not cover the entire area of vegetation disturbance in every case, the strength of the relationship shown in Figure 3 may have been influenced by the inherent uncertainties in these two variables.

It is worth noting that the term forest or tree 'damage' refers to different levels of ecosystem disturbance in the numerous previous publications cited in this study, and consequently, the term is commonly ill-defined in many of these citations. For the purpose of clarity of the QUICC product evaluation, 'damage' is defined as a loss of the majority of canopy tree (leaf area) cover and loss (blow-down) of the majority of tree stems per unit forested area. This clear definition of terms should enable QUICC users to be informed of the potential advantages of the QUICC product, but also cautioned about the potential limitations to properly interpret the results.

Tree damage and mortality from intense storm events can result in measurable transfers of live standing wood biomass to down and dead carbon pools (McNulty 2002). If TS events increase in intensity or frequency in a warming climate, this shift in live to dead biomass stocks can reduce standing vegetation pools of carbon, accelerate ecosystem respiration fluxes of carbon dioxide and thereby represent a potentially significant positive feedback to terrestrial greenhouse gas emissions (Negrón-Juárez et al. 2010; Vargas 2012). Chambers et al. (2007), for example, estimated that Hurricane 


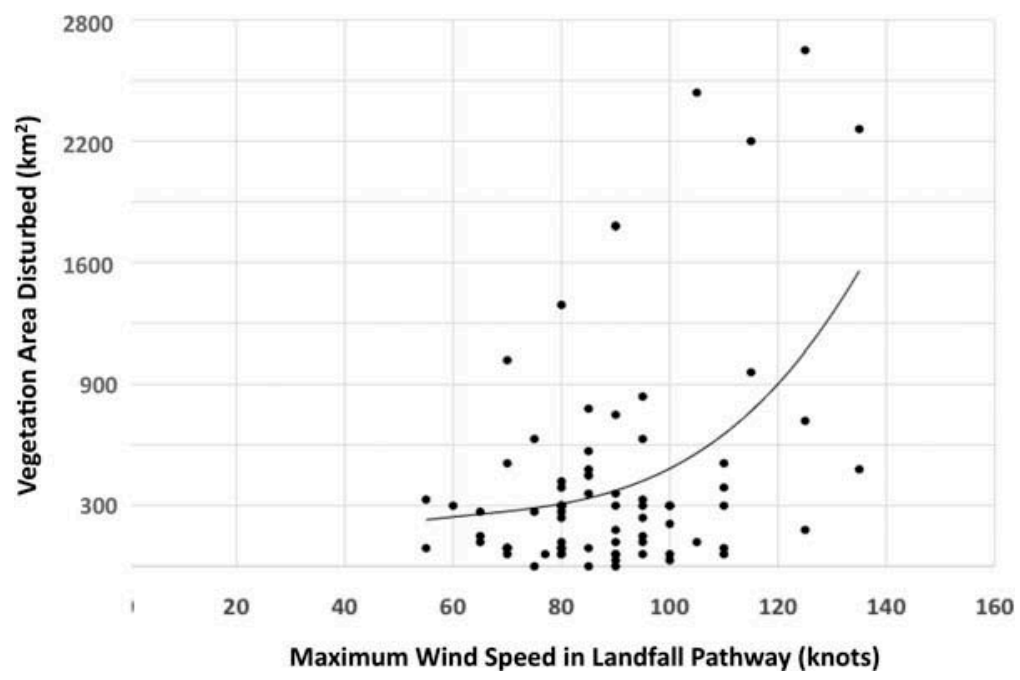

Figure 3. Total area $\left(\mathrm{km}^{2}\right)$ of QUICC 5600-m resolution pixels detected along TS 50-km landfall buffer zones versus MWS (knots) reported in landfall pathways in the IBTrACS database (as listed in Table 1). The two TS events detected with the largest areas of vegetation disturbance by QUICC image analysis were statistical outliers and therefore were not included in this plot, namely cyclones Fanele and Yasi. The positive exponential correlation was statistically significant at $p<0.01(n>70)$.

Katrina caused mortality or severe structural damage to 320 million trees, with a total biomass loss equivalent to $50-140 \%$ of the net annual US carbon sink in forest stands. Major changes in the land surface albedo can result from disturbed forest cover (NegrónJuárez et al. 2008). There is also mounting historical evidence that strong hurricanes promote the subsequent occurrence of forest fires of higher than normal intensity (Myers and van Lear 1998; Liu, Lu, and Shen 2008). Therefore, validation of new methodologies that can quantify forest disturbance zones globally is a critical component in understanding the widespread impacts of large-scale TS disturbances.

The results of this worldwide assessment confirm that the MODIS QUICC product can reliably detect extensive tropical forest damage following extreme storm events. The QUICC methodology was conceived to be a computationally simple, early alert product, designed primarily to identify large areas of tropical forest disturbance. These features make timeliness the greatest advantage for QUICC users to identify possible new areas of deforestation and degradation. Subsequent accuracy assessments of QUICC products from human-caused deforestation must derive from site visits and surveys to verify the varied causes and consequences of tropical ecosystem change.

\section{References}

Brokaw, N. V. L., and L. R. Walker. 1991. "Summary of the Effects of Caribbean Hurricanes on Vegetation." Biotropica 23: 442-447. doi:10.2307/2388264.

Chambers, J. Q., J. I. Fisher, H. Zeng, E. L. Chapman, D. B. Baker, and G. C. Hurtt. 2007. "Hurricane Katrina's Carbon Footprint on US Gulf Coast Forests." Science 318: 1107. doi:10.1126/science. 1148913 .

Emanuel, K. 2005. "Increasing Destructiveness of Tropical Cyclones over the Past 30 Years." Nature 436: 686-688. doi:10.1038/nature03906.

Huete, A., K. Didan, T. Miura, E. P. Rodriguez, X. Gao, and L. G. Ferreira. 2002. "Overview of the Radiometric and Biophysical Performance of the MODIS Vegetation Indices." Remote Sensing of Environment 83: 195-213. doi:10.1016/S0034-4257(02)00096-2. 
Knapp, K. R., M. C. Kruk, D. H. Levinson, H. J. Diamond, and C. J. Neumann. 2010. "The International Best Track Archive for Climate Stewardship (IBTrACS)." Bulletin of the American Meteorological Society 91: 363-376. doi:10.1175/2009BAMS2755.1.

Lehmann, E. 2006. Nonparametrics: Statistical Methods Based on Ranks, 464. New York: Springer. ISBN: 978-0387352121.

Lewis, R. J., and K. H. Bannar-Martin. 2012. "The Impact of Cyclone Fanele on a Tropical Dry Forest in Madagascar." Biotropica 44 (2): 135-140. doi:10.1111/j.1744-7429.2011.00799.x.

Liu, K., H. Lu, and C. Shen. 2008. "A 1200-Year Proxy Record of Hurricanes and Fires from the Gulf of Mexico Coast: Testing the Hypothesis of Hurricane-Fire Interactions." Quaternary Research 69: 29-41. doi:10.1016/j.yqres.2007.10.011.

LP-DACC: NASA Land Processes Distributed Active Archive Center. 2007. MODIS/Terra Vegetation Indices Monthly L3 Global 0.05 Deg CMG. Sioux Falls: USGS/Earth Resources Observation and Science (EROS) Center.

McNulty, S. G. 2002. "Hurricane Impacts on US Forest Carbon Sequestration." Environmental Pollution 116: S17-S24. doi:10.1016/S0269-7491(01)00242-1.

Myers, R. K., and D. H. van Lear. 1998. "Hurricane-Fire Interactions in Coastal Forests of the South: A Review and Hypothesis." Forest Ecology and Management 103: 265-276. doi:10.1016/S0378-1127(97)00223-5.

Negrón-Juárez, R., D. B. Baker, H. Zeng, T. K. Henkel, and J. Q. Chambers. 2010. “Assessing Hurricane-Induced Tree Mortality in US Gulf Coast Forest Ecosystems." Journal of Geophysics Research 115: G04030. doi:10.1029/2009JG001221.

Negrón-Juárez, R. I., J. Q. Chambers, H. Zeng, and D. B. Baker. 2008. "Hurricane Driven Changes in Land Cover Create Biogeophysical Climate Feedbacks." Geophysics Research Letters 35: L23401. doi:10.1029/2008GL035683.

North Carolina Forest Service (NCFS). 2011. Hurricane Irene Timber Damage Summary, 7. Raleigh: North Carolina Department of Agriculture and Consumer Services.

OCHA. 2009. United Nations Office for the Coordination of Humanitarian Affairs - Integrated Regional Information Networks (2009-01-22). Madagascar: Cyclone Double Whammy.

Potter, C., V. Kumar, S. Klooster, and R. Nemani. 2007. "Recent History of Trends in Vegetation Greenness and Large-Scale Ecosystem Disturbances in Eurasia." Tellus B 59: 260-272. doi:10.1111/j.1600-0889.2006.00245.x.

Potter, C., P. Tan, V. Kumar, C. Kucharik, S. Klooster, V. Genovese, W. Cohen, and S. Healey. 2005. "Recent History of Large-Scale Ecosystem Disturbances in North America Derived from the AVHRR Satellite Record." Ecosystems 8 (7): 808-824. doi:10.1007/s10021-005-0041-6.

Rogan, J., L. Schneider, Z. Christmanab, M. Millones, D. Lawrence, and B. Schmook. 2011. "Hurricane Disturbance Mapping Using MODIS EVI Data in the Southeastern Yucatán, Mexico." Remote Sensing Letters 2 (3): 259-267. doi:10.1080/01431161.2010.520344.

Sun, H. 2011. "Sugar Price Soars on US Markets as Cyclone Yasi Hits Queensland.” Accessed February 3. http://www.news.com.au/finance/sugar-price-soars-on-us-markets-as-cyclone-yasi-hits-queensland/ story-e6frfm1i-1225999207987

Vargas, R. 2012. "How a Hurricane Disturbance Influences Extreme $\mathrm{CO}_{2}$ Fluxes and Variance in a Tropical Forest." Environmental Research Letters 7 (3): 035704. doi:10.1088/1748-9326/7/3/035704.

Weinkle, J., R. Maue, and R. Pielke Jr. 2012. "Historical Global Tropical Cyclone Landfalls." Journal of Climate. 25: 4729-4735. doi:10.1175/JCLI-D-11-00719.1.

Whigham, D. F., I. Olmsted, E. C. Cano, and M. E. Harmon. 1991. "The Impact of Hurricane Gilbert on Trees, Litterfall, and Woody Debris in a Dry Tropical Forest in the Northeastern Yucatan Peninsula." Biotropica 23: 434-441. doi:10.2307/2388263.

WMO. 1983. Measurement of Surface Wind. Guide to Meteorological Instruments and Methods of Observation. 5th ed., 121-134. Geneva: World Meteorological Organization.

Zhao, D. H., B. Allen, and R. R. Sharitz. 2006. "Twelve-Year Response of Old-Growth Southeastern Bottomland Hardwood Forests to Disturbance from Hurricane Hugo." Canadian Journal of Forest Research 36: 3136-3147. doi:10.1139/x06-204.

Zimmerman, J. K., E. M. Everham III, R. B. Waide, D. J. Lodge, C. M. Taylor, and N. V. Brokaw. 1994. "Responses of Tree Species to Hurricane Winds in Subtropical Wet Forest in Puerto Rico: Implications for Tropical Tree Life Histories." The Journal of Ecology 82: 911-922. doi: $10.2307 / 2261454$. 